\title{
Hypoglycaemic Activity and Biochemical Effects of Cataranthusroseus with Diabenese in Normal and Diabet IC Rats
}

\author{
Jones B.B ${ }^{1}$, Tabe N. $\mathbf{N}^{1}$, UshieO. $\mathbf{A}^{2} *$ \\ ${ }^{l}$ Department of Chemical Science, Cross River University of Technology Calabar, Nigeria \\ ${ }^{2}$ Department of Chemical Science, Federal University Wukari Nigeria
}

*Corresponding Author: Ushie O.A, Department of Chemical Science, Federal University Wukari Nigeria.

\begin{abstract}
The hypoglycaemic activity and biochemical effects of cataranthusroseus with diabenese in normal and diabetic rats were compared. Ethanollic extract of $C$. roseus were screened for their phytochemical constituents using standard methods. Biochemical effects were evaluated on alloxan induced diabetic rat (32) assigned into four study groups of eight rats each Group 1 (control) received diabinse (14.28mg/kg). C roseus $(400 \mathrm{mg} / \mathrm{kg}$ ) all in $30 \%$ ethanol. At the end of 21 day administration period blood serum was obtained from sacrificed animals and biochemical indices of toxicity (lipid profile, aminotransferases activity, serum protein, urea and albumin.
\end{abstract}

\section{INTRODUCTION}

Diabetes mellitus is a chronic endocrinologic disorder characterized by high blood glucose levels arising from insufficient secretion of insulin by the pancreas or improper utilization by target cells. Diabetes is the most common endocrinologic disorder with widespread prevalence cutting across all populations groups (Report of the expert committee on Diagnosis and classification of diabetes mellitus, 1998).The insufficient secretion of insulin by pancreatic islet calls or detective insulin receptors.Leads to poor utilization of insulin by target cells culminating in raised fasting blood glucose levels (>8mmoi/L) glycosylated haemoglobin $(\mathrm{Hb} \mathrm{A} / \mathrm{C})$ greater than $6-9 \%$. Glycosylated haemoglobin gives and indication of average blood glucose concentration over a $6-8$ week period and is a biochemical test used for monitoring progression of diabetes or response to treatment. While the capillary or a venous glucose valve gives the blood glucose levels. Besides the immediate perceptible metabolic disfunction accompanying hyperglycemia. There are long - term complication of diabetes mellitus involving disorders of the eyes, kidneys, nerves and blood vessels.

The Canadian Diabetes Association (2003), reported three main types diabetes: Type 1 diabetes usually diagnosed in children and adolescence which occurs when the pancreas is unable to produce insulin necessary to meets the energy needs of tissues required in the body. About 10 percent of people with diabetes have type I diabetes. It is also called insulin dependent Diabetes. The remaining 90 percent of diabetes have type II diabetes that occurs when the pancreas does not produce enough insulin or body does not effectively use insulin that is produce and is developed in adulthood.

A third type, gestational diabetes which is a temporary condition, occurs during pregnancy. It affects 3.55 percent of all pregnancies and present an increased risk of developing diabetes for both mother and child in later life (Mayfield 1998; Canadian diabetes association 2003). According to Clavell (2002) report on Diabetes Management as documental by the Mayo foundation for Medical Education and Research in New York identified a forth type of diabetes arising from illness or medications that can interface with production of insulin or its action. Approximately 1-2\% of all diagnosed cases belongs to this group and include inflammation of the pancreases, pancreatomy, adrenal or pituitary disorders hydrocortisones treatments for another disease, some high blood pressure and Cholesterol lowering medications malnutrition and infection.

Diabetes is a syndrome of disturbed intermediary metabolism diabetes mellitus commonly concomitant with hypertension and other disease (Greff, 2000). It is therefore not a single disease entity but has been described to be a syndrome characterized by an absolute or relative lack of insulin 
leading to persistent elevation of blood glucose as well as alteration in lipid and fat metabolism (spencer and cudworth 1989).A lot of specific secondary causes can lead to this syndrome. These include pancreectomyheamachromatosis including iron over load of beta cells excessive cortisol production (cushing syndrome) excessive growth hormone production as in agromegally, insulin resistant syndrome occasioned in part by insulin receptor defects (Lernmarket al, 1981; Laakoet al, 1988) where the patients does not show these defects, he is said to have idiopathic diabetes (WHO, 1995).

\section{Materials ANd Methods}

The ethanolic extracts of Cataranthusroseuswere subjected to phytochemical screening to establish their phytochemical compositions. Ninety rats (Males and Females) of wistar strain weighing 140$245 \mathrm{~g}$ obtained from the animal house. Department of Biochemistry, University of Calabar.Diabetes was induced on a pool of seventy rats by intraperitioneal injection of $150 \mathrm{mg} / \mathrm{kg}$ body weight of alloxan monohydrate (Sigma, st Louis, Mo. USA). Using distilled water as the vehicle.The research work was organised, into phases. Phase 1 and phase 11. The first consisted of 24 diabetic and nondiabetic (normal) animals respectively assigned into 4 groups of six rats each. These were used for hypoglycaemic assessment only on the hand. The second phase consisted of purely diabetic animals (32 animals) also assigned into 4 groups of eight each and tread as in phase 1.

Treatment was administered twice a day by gastric intubation in a 12 hour cycle $7.00 \mathrm{am}$ and $7.00 \mathrm{pm}$ everyday for 14days. Body weight of the animal monitored after every two days throughout the administration period using a beam balance. Twelve hours after last feeding and administration (overnight fast) the animals were anesthetized under chloroform vapour then dissected. Whole blood was collected from the heart by cardiac puncture and divided into two fractions. Serum triglyceride level was estimated with the use of Dialab laboratory kit. The method employs enzymatic hydrolysis of triglyceride in the sample with lipoprotein lipase (LPL).In Hayems and Turks fluids a 1:200 dilution of blood was made by taking 20 microlitres of blood in a glass tube $(75 \times 12 \mathrm{~mm})$. The tube sealed with rubber band was tilted through an eagle of 120 and rotated for 2 minutes. With a Pasteur pipette. the country chamber (New improved neubauer country chamber) was filled with the diluted blood sample, ensuring that no blood spilled into surrounding moat, The cells were allowed to settle by leaving the chamber undisturbed for 2 minutes, after which the cells were counted under low magnification ( $4 \mathrm{~mm}$ dry objective and x 10 eye piece). The country involved cells in the four squares at the corners of the chamber of WBC as well the cells in the centre square alongside those in the squares at the corners for the RBC.

\subsection{Statistical}

Data obtained was expressed as meant standard deviation and analysed the Analysis of variance (ANOVA) or student's t-test where applicable. Values $\mathrm{P}<0.05$ were regard as significant in comparison to appropriate controls.

\section{RESUltS}

Phytochemical composition of Catharanthusroseus extract shows the ethanolicleaf extracts of $C$ roseus contain various phytochemical components which differ in their relative abundance. They include cardiac glycosides, sapouins, tannins and anthraquinones which showed slight presence.Effect of treatment on blood glucose concentration of rats show comparative effect of ethanoic extracts of Cataranthusroseus and diabinese treatment on serum glucose of diabetes rats. The treatment with these drugs reduced significantly $(\mathrm{P}<0.05)$ serum glucose levels of normal non-diabetic animals $(81.32 \pm 5.32$, and $78.64 \pm 6.47$ for diabinese, and Cataranthus respective) and diabetic rats (163.05 \pm 3.75 , and $105.61 \pm 3.62$ respectively) for diabeinese and Cataranthusroseus relative to their respective controls (107.88 and $247 \pm 4.83$ for normal and diabetic rats).

Table1. Comparative effect on fasting blood glucose $(\mathrm{mg} / \mathrm{dl})$ following a 21day administration of diabineseCataranthusroseu extracts on normal and diabetic rats.

\begin{tabular}{|c|c|c|}
\hline Treatment groups rat & Normal-Diabetic rats & Diabetic rat \\
\hline Control $(30 \%$ ethanol & $107.88 \pm 7.38$ & $247.25 \pm 4.83$ \\
\hline Diabinese treated $(14.29 \mathrm{mg} / \mathrm{kg})$ & $* 81.31 \pm 5.32$ & $* 163.05 \pm 3.75$ \\
\hline C roseus treated $(400 \mathrm{mg} / \mathrm{kg})$ & $* 78.64 \pm 6.47$ & $* 105.61 \pm 3.63$ \\
\hline
\end{tabular}

Values of expressed as mean $\pm \mathrm{SD},=6$

$*=$ Statistically significant $(\mathrm{P}<0.05)$ compared with controls values without asterisks are not significant. 
Hypoglycaemic Activity and Biochemical Effects of Cataranthusroseus with Diabenese in Normal and Diabet IC Rats

\subsection{Effect of Treatment on Serum Lipid Fraction of Diabetic Rats}

The comparative effectsethanolic extracts of Cataranthusroseus and diabetes on serum lipid fractions including Total cholesterol. Triglycerides (TG) and High density lipoprotein have been shown in table 3 Treatments with diabinse produce decreases in Total Cholesterol and Triglycerides but an increase in High density lipoprotein of these changes only that of Triglycerides was significant $(88.16 \pm 25.41)$ compared to the control $(142.19 \pm 40.13)$. Treatment with diabinse however, caused significant decrease $(\mathrm{P}<0.05)$ in High density lipoprotein level $(33.99 \pm 8.25)$ and a decreases in total cholesterol $(63.62 \pm 16.11)$ and triglycerides $(86.16 \pm 18.92)$ compared to their respective controls. The decreased was only significant in total cholesterol $(\mathrm{P}<0.05)$ and not total cholesterol.

Table2. Comparative effect of diabinese, ethanolic extracts of $C$ rosesus on serum lipids of diabetic rats treated for 21 days.

\begin{tabular}{|c|c|c|c|}
\hline Treatment Groups & $\begin{array}{c}\text { Total Cholesterol } \\
(\mathrm{mg} / \mathrm{dl})\end{array}$ & $\begin{array}{c}\text { Triglycerides } \\
(\mathrm{mg} / \mathrm{dl})\end{array}$ & $\begin{array}{c}\text { High density } \\
\text { Lipoprotein }(\mathrm{mg} / \mathrm{dl})\end{array}$ \\
\hline Diabetic Control & $69.98 \pm 9.50$ & $142.19 \pm 40.13$ & $43.10 \pm 4.00$ \\
\hline Diabetic Diabinse treated & $63.62 \pm 16.11$ & $* 88.16 \pm 18.92$ & $39.99 \pm 8.25$ \\
\hline Diabetic C roseus treated & $60.08 \pm 8.22$ & $* 86.59 \pm 22.76$ & $* * 60.05 \pm 7.87$ \\
\hline
\end{tabular}

Values represented mean $\pm \mathrm{SD} n=8$

$*=$ Statistically significant $(\mathrm{P}<0.05)$ compared with the control

$* *=$ Statistically significant $(\mathrm{P}<0.01)$ compared with the control are not significant.

Table3. Comparative effect of a 21 day treatment with diabinese ethanolic extract of $\underline{C}$. reseus on serum levels of total protein, albumin and urea of diabetic rats

\begin{tabular}{|c|c|c|c|}
\hline Treatment Group & Total Protein $(\mathbf{g} / \mathbf{d l})$ & Albumin $(\mathbf{g} / \mathbf{d l})$ & Urea $(\mathbf{m g} / \mathbf{d l})$ \\
\hline Diabetic control & $7.16 \pm 0.52$ & $3.43 \pm 0.14$ & $7.30 \pm 6.67$ \\
\hline Diabetic diabinese treated & $* 8.41 \pm 0.98$ & $3.39 \pm 0.34$ & $* * 12.63 \pm 0.29$ \\
\hline $\begin{array}{c}\text { Diabetic cataranthusroseus } \\
\text { treated }\end{array}$ & $* * 8.31 \pm 0.18$ & $* 3.33 \pm 0.30$ & $* * 25.17 \pm 7.31$ \\
\hline
\end{tabular}

Values represent mean \pm SD $n=8$

$*$ = Statistically significant $(\mathrm{P}<0.05)$ compared with control

$* *=$ Statistically significant $(\mathrm{P}<0.01)$ compared with control

Treatment effect on aminotransferaces activity of diabetic rats.Aminotransferace activities was determined and the results serum AST activity decreased in treatment $(101.00 \pm 10.42$ and $102.60 \pm$ 8.23 for diabetic diabinese treated and diabetic Cataranthusroseus. Compared to the control (110.13 \pm 14.26). The decreases were however, non significant $(\mathrm{P}>0.05)$ Serum ALT activity in serum also decreased upon treatment $(14.62 \pm 2.90,15.50 \pm 3.60$ and $13.13 \pm 1.31$, diabetic diabinese treated. The decrease in ATL was only significant $(\mathrm{P}<0.05)$ in the group treated with $C$. roseus. The presence of these substances may be responsible for their anti hyperglycaremia action. Win/eman (1989) had earlier in his report indicated that plants endowed with flavoids. glycosides and phytosterols are likely to posses both hypoglycaemia and antihyperglycemic action. Serum lipid fraction information available from pathophysiology reveals that it is associated with lipoprotein abnormalities due to defect in insulin, which is an antihyperglyceridemic and lipogenic hormone. As a consequence diabetes haveincrease risk for development of premature atherosdenosis due to the increased HDL levels (Bierman. 1992).

In this study total cholesterol and triglycerides raised in diabetes controls were reduced significantly following treatment with the herbs and diabinese.Nimenibo-Uadia.(2003) and Uhegbu and Ogbuehi (2004). The saponins are taught to bind cholesterol to bile acids. Consequently lowering cholesterol in plasmic (Nimeribo-Uadia, 2003).However, the effects of $C$. rose us and to a lesser extent diabetes are more beneficial with respect to HDL whereas $C$. rose us increased significantly the levels of HDL. 


\section{CONCLuSiON}

Some of the indices assayed after 21days administration period indicates that the herbs could protect the diabetic animals better than the standard drug. The herbs also proved more efficacious in their hypoglycemic action. Cataranthusroseus are very efficacious, in its hypoglycemic and antihypoglycemic action than the standard drug. C.roseusalso proved to posses the ability to reverse hyponatreamia seemingly induced by diabinese treatment. C. roseuscould protect the rats against damage on the heamatopoetic tissue i.eieucopenia caused by diabinese treatment.Cataranthusroseus might give a better and holistic protection as it is the only in the study with a vantage and positive impact on HDL cholesterol (good cholesterol).

\section{REFERENCES}

[1] Canadian Diabetes Association (2003). Clinical practice guidelines for prevention and management of diabetes in Canada. Ontario: Canadian Diabetes Association.

[2] Banley, C. V. \& Day, C. (1989). Traditional treatment for diabetes

[3] Spencer K. M \& Cud Worth, A. G. (1989). Diabetes in epidemiological.

[4] Lernmark, A. Hagglof. D \& Freedman. W. (1981). A prospective analysis of antibodies reacting with pancreatic islet cells in Insulin dependent diabetic children. Diabetologia. 20.471- 474.

[5] Clavell. M. C. (2002). Managing diabetes in Mayo, I. (ed). Mayo Foundation For medical education and research ( $2^{\text {nd }}$ edition) (pp.5-20). New York: Kensington press.

[6] Nimenibo-Uadia, R. (2003). Effect of Vernoniaamygdalina in alloxan-induced diabetes albino rats. Journal of Medical Laboratory Science. 12(1) 25-31.

[7] Thompson. L. U. (1993) Potential health benefits and problems associated with antinutrients in food Research International. 26, 137-149.

[8] World Health Organization.(1985). World health organization study group technical report on diabetes mellitus. Geneva. World Health Organization.

[9] Greoff, O. R. W. (2000). The Management of diabetes mellitus. GeneeSkunde: The Medicine Journal. October 2000. Retrievedon October 5.2005 from hitt//www.med pharm.co.2a/safp/2000/oct/mellitus: html.

[10] Wineleman. M. (1989). Ethnobotanical treatment of diabetes. Baja medical Anthropology II

[11] Bierman, E.L. (1992). Artherosierosis in diabetes. Artheroserosis and thrombosis 12, $647-656$.

[12] Nimenibo - Uadia, R. (2003). Efect of vernomiaamgadalina in alloxan - indeed diabetes albino rats. Journal of medical laboratory Science. 12 (1).

[13] Uhegbu, F.O \&Ogbuehi, J. (2004). Effect of aqueous extract (cruele) of leaves of veronnia amygdaline. Del on blood glucose serum albumin and cholesterol level in diabetic albino rats. Global Journal of pure and Applied Science, 10, $189-194$.

[14] Nimoibouadia (2003) argued that the sapronmia are likely to cause blood glucose reduction via their effect on plasma lipids. Furthermore, Mccune and Jolius (2002) in a survey of medicinal plants (35) of North America revealed that the phytochemicals of these plants support a lifestyle historically low in the incdence of diabetes in Canada (North America).

Citation: jones B, et.al. (2019). "Hypoglycaemic Activity and Biochemical Effects of Cataranthusroseus with Diabenese in Normal and Diabet IC Rats". International Journal of Clinical Chemistry and Laboratory Medicine (IJCCLM), 5(2), pp. 9-12, DOI: http://dx.doi.org/10.20431/2455-7153.0502002.

Copyright: () 2019 Authors. This is an open-access article distributed under the terms of the Creative Commons Attribution License, which permits unrestricted use, distribution, and reproduction in any medium, provided the original author and source are credited. 